\title{
Various Extracts of Some Medicinal Plants as Inhibitors for Beta-lactamase Activity
}

\author{
Huda S. A. Al-Hayanni ${ }^{*}$
}

Hamed M. El-Shora ${ }^{2 *}$

\author{
${ }^{1}$ Biology Department, College of Science for Women, University of Baghdad, Iraq \\ ${ }^{2}$ Botany Departments, Faculty of Science, Mansoura University, Egypt \\ *Corresponding author: hudasa_bio@csw.uobaghdad.edu.iq ${ }^{*}$, shoraem@yahoo.com, shora@mans.edu.eg \\ "ORCID ID https://orcid.org/0000-0002-3074-1331", https://orcid.org/0000-0003-1897-9336
}

Received 28/11/2019, Accepted 13/10/2020, Published Online First 6/12/2020, Published 1/3/2021

This work is licensed under a Creative Commons Attribution 4.0 International License.

\begin{abstract}
:
The inhibitory effect of acetone, ethanol, and aqueous extracts of ten medicinal plants on $\beta$ lactamase from Staphylococcus sciuri and Klebsiella pneumoniae was investigated in vitro by starch-iodine agar plate method. The results revealed the success of starch-iodine method for the detection of the inhibition of $\beta$-lactamase activity by the various extracts of each individual plant. The acetone extracts of Catharanthus roseus, Eucalyptus camaldulensis, and Schinus terebinthifolius induced an inhibitory effect on $\beta$-lactamase from Staphylococcus sciuri. On the other hand, acetone extracts from only Eucalyptus camaldulensis, and Schinus terebinthifolius expressed strong inhibitory effect on $\beta$-lactamase from Klebsiella pneumoniae. The acetone extracts expressed the highest inhibition for $\beta$-lactamases activity compared to ethanolic and aqueous extracts which exhibited appreciable inhibitory effect. $\beta$-lactamase from $S$. sciuri was inhibited by extracts from $C$. roseus, E. camaldulensis and $S$. terebinthifolius whereas $\beta$-lactamase from $K$. pneumoniae was inhibited only by extracts from E. camaldulensis and S. terebinthifolius.
\end{abstract}

Key words: Antibacterial activity, Klebsiella pneumonia, Medicinal plants, $\beta$-lactamase, Staphylococcus sciuri.

\section{Introduction:}

$\beta$-lactamase catalyzes the hydrolysis of the $\beta$ lactam ring, thereby inactivating $\beta$-lactam antibiotics(1). $\beta$-lactam is one of the most essential groups of antibiotics. In bacteria, the crucial method of $\beta$-lactam resistance is the production of $\beta$ lactamase which inhibits the $\beta$-lactams by way of disrupting the amide bond of their $\beta$-lactam ring (2).

The incidence of multi-drug resistance bacteria has been increasingly reported currently among Gram-negative and Gram-positive bacteria (3). Thus, other antimicrobial bacterial agents are necessary to be advanced to control bacteria with multi-drug resistant. To face this challenge, there has been increasing interests to discover antimicrobial agents from medicinal plant extracts as an alternate strategy $(4,5,6)$.

The application of $\beta$-lactamase inhibitors coupled with $\beta$-lactam antibiotic is now the foremost valuable strategy to treat a range of infections. The role of these enzyme inhibitors is the inhibition of the $\beta$-lactamase in the periplasmic space. Inhibitors of $\beta$-lactamase including tazobactam, sulbactam, and clavulanic acid are extracted from natural products or manufactured for improving the drugs. However, bacterial resistance to these inhibitors has considerably increased (7).

Traditionally, the use of plants in illness treatment has deep roots in human's history (8). The practice of natural compounds with therapeutic features is as ancient as man civilization. Animal, plant and mineral products remain the basic sources of drugs (3). Several publications described activity of medicinal plants as $\beta$-lactamase inhibitors (9) either as extracts or products $(10,7,2)$.

The present work aims to isolate, purify $\beta$ lactamase from Staphylococcus sciuri and Klebsiella pneumonia and study the effect of various extracts from ten medicinal plants on their enzyme activities.

\section{Material and Methods: \\ Bacterial strains}

Staphylococcus sciuri and Klebsiella pneumonia used in the present study were taken from Clinical Microbiology Lab in Faculty of Medicine, Mansoura University, Dakahlia Governorate, Egypt. They were screened for $\beta$ - 
lactamase production and identified in the Lab of Microbiology, Mansoura University hospital for children using Microscan Walk A way system.

\section{Preparation of $\beta$-lactamase extract}

The isolation and enzyme purification from both bacteria were carried out according to Ranade et al. (11) at $4^{\circ} \mathrm{C}$ by $80 \%$ ammonium sulphate precipitation, DEAE-cellulose and Sephadex G-200 column. $\beta$-lactamase activities were 327 and 268 units per min form $K$. pneumoniae and $S$. sciuri
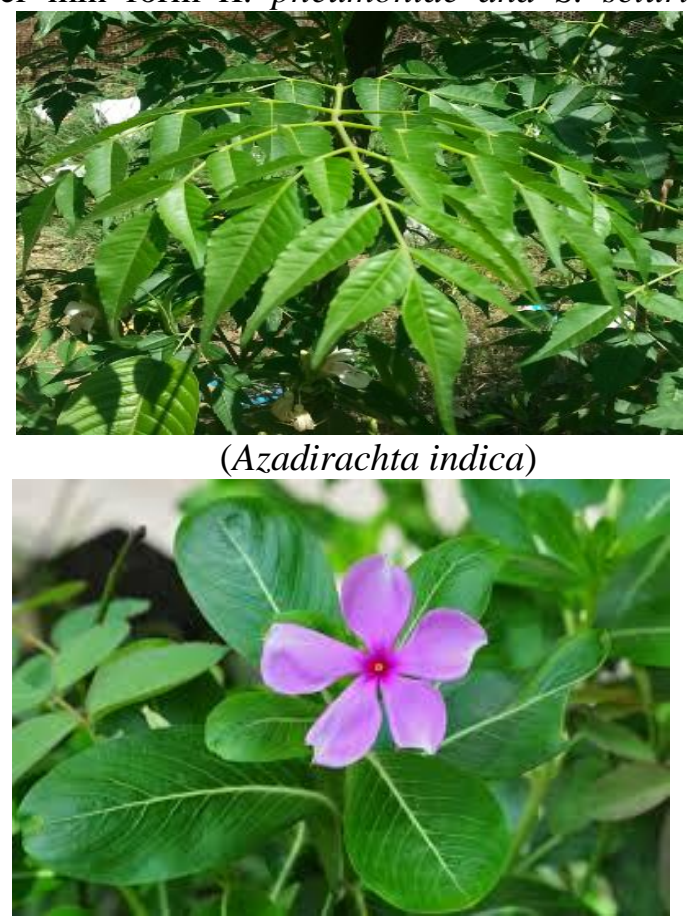

(Catharanthus roseus)

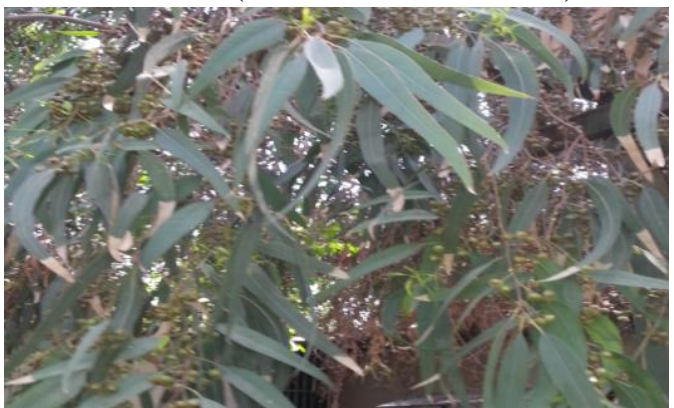

(Eucalyptus camaldulensis)

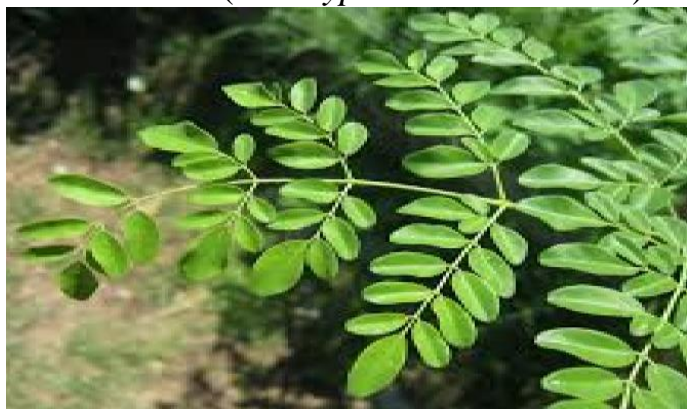

(Moringa oleifera) whereas the specific activities were 280 and 230 units $\min ^{-1} \mathrm{mg}^{-1}$ protein, respectively.

\section{Collection of medicinal plants}

The leaves of ten medicinal plant species (Fig. 1) were collected from the garden of Mansoura University, Dakahlia Governorate, Egypt. The plants were identified by Prof. Dr ElSayed El-Halawany, Prof. of Plant ecology, Botany Department, Faculty of Science, Mansoura University, Egypt.
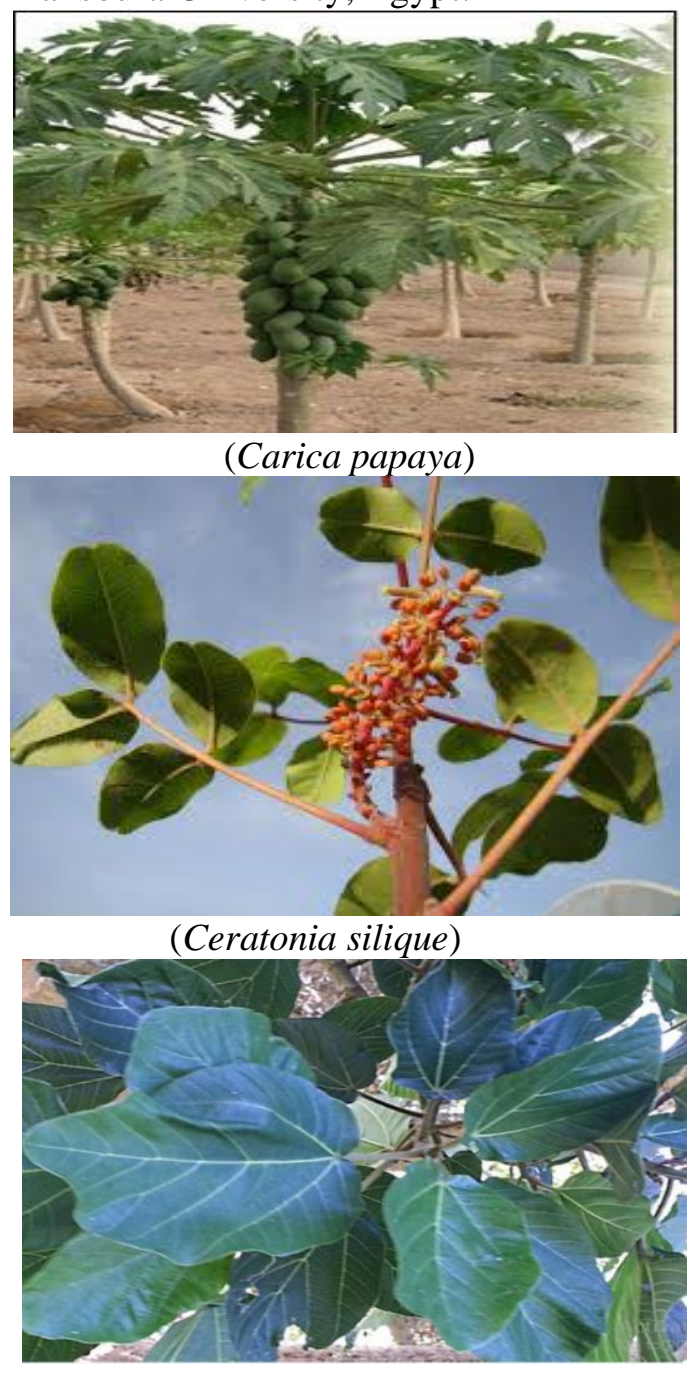

(Ficus sycomorus)

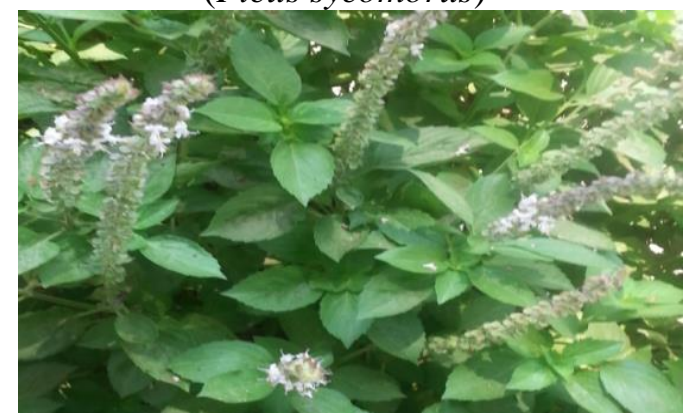

(Ocimum basilicum) 


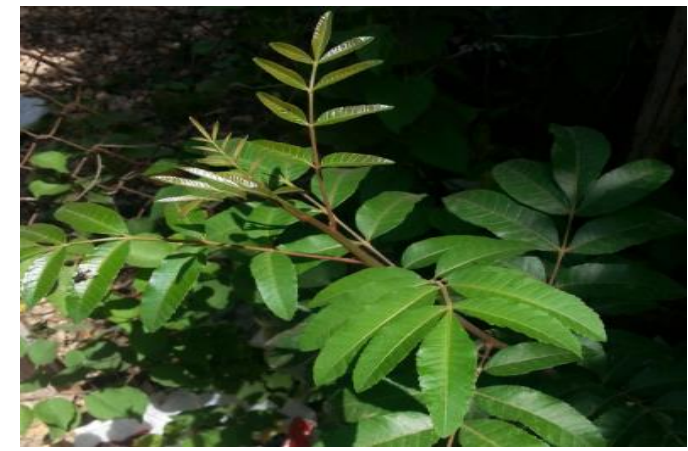

(Schinus terebinthifolius)

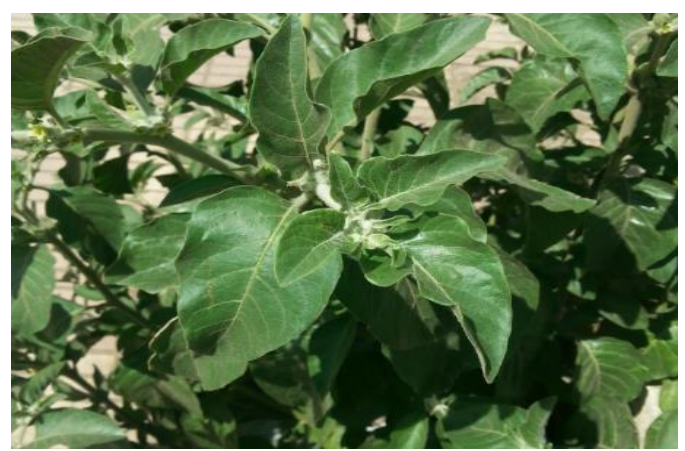

(Withania somnifera)

Figure 1. The ten investigated medicinal plants.

\section{Preparation of plant extracts}

Fresh leaves from each tested plant were totally rinsed with running water twice, air dried and stored at room temperature (12). The dried tested leaves were pulverized with blender and then stored at room temperature until use. Acetone, ethanol and aqueous extracts were accomplished according to Djeussi et al. (13). The resulting mixture was macerated using a shaker incubator for $24 \mathrm{~h}$ at $37^{\circ} \mathrm{C}$. The residual solvent was removed by evaporator and stored at $4^{\circ} \mathrm{C}$. The crude extracts were kept in sterilized containers at $4^{\circ} \mathrm{C}$ till uses.

Effect of medicinal plant extracts on $\beta$-lactamase in vitro by starch-iodine agar plate method

A sample of $0.5 \mathrm{ml}$ of iodine solution $(5 \mathrm{~g}$ of iodine and $15 \mathrm{~g}$ of KI were dissolved in $100 \mathrm{ml}$ of distilled water) was added to the plate filled with the hot agar solution (each $100 \mathrm{ml}$ distilled water contained $500 \mathrm{mg}$ soluble starch and $2 \mathrm{~g}$ agar). The solution was stirred and left at room temperature for solidification before use in a lapse of $4 \mathrm{~h}$ (14).

\section{Screening test}

Thirteen wells of $5 \mathrm{~mm}$ in diameter were nicked in the prepared plates by a sterile Cork borer. A negative control was represented by well $\mathrm{A}$ that contained $0.1 \mathrm{ml}$ of phosphate buffer $(\mathrm{pH} 7.0)$ plus $0.1 \mathrm{ml}$ of penicillin $\mathrm{G}\left(50 \mathrm{mg} \mathrm{ml}^{-1}\right.$ in the same buffer). Well B was filled with $0.05 \mathrm{ml}$ of phosphate buffer ( $\mathrm{pH} 7.0$ ) and $0.05 \mathrm{ml}$ of $\beta$-lactamase solution with $0.1 \mathrm{ml}$ of penicillin $\mathrm{G}\left(50 \mathrm{mg} \mathrm{ml}^{-1}\right)$. As positive control, well $\mathrm{C}$ contained $0.05 \mathrm{ml}$ of $\beta$ lactamase solution, $0.05 \mathrm{ml}$ of $\mathrm{HgCl}_{2}$ and $0.1 \mathrm{ml}$ of penicillin $\mathrm{G}\left(50 \mathrm{mg} \mathrm{ml}^{-1}\right)$ after $10 \mathrm{~min}$. Wells (1-10) were filled with $0.05 \mathrm{ml}$ of plant extracts solution $\left(10 \mathrm{mg} \mathrm{ml}^{-1}\right), \quad 0.05 \mathrm{ml}$ of $\beta$-lactamase solution and $0.1 \mathrm{ml}$ penicillin $\left.\mathrm{G} \quad(50 \mathrm{mg} \mathrm{ml})^{-1}\right)$. Well $\mathrm{D}$ contained plant extract, penicillin and $\beta$-lactamase solutions. The concentration $10 \mathrm{mg} \mathrm{ml}^{-1}$ of plant extract was chosen since it was the most effective one after testing various concentrations.

The prepared plates were then incubated for $30 \mathrm{~min}$ at $35{ }^{\circ} \mathrm{C}$. The resulted transparent zones around the wells were measured in millimeters (Fig.
2). The inhibition rate can be calculated as follows: Inhibition rate $(\%)=$

Zone diameter without inhibitor -

$\frac{\text { zone diameter with inhibitor }}{\text { Zone diameter without inhibitor }-5 *} \times 100$

$5^{*}$ is the diameter of well. The data were expressed as mean \pm standard deviation (SD) of three replicates.

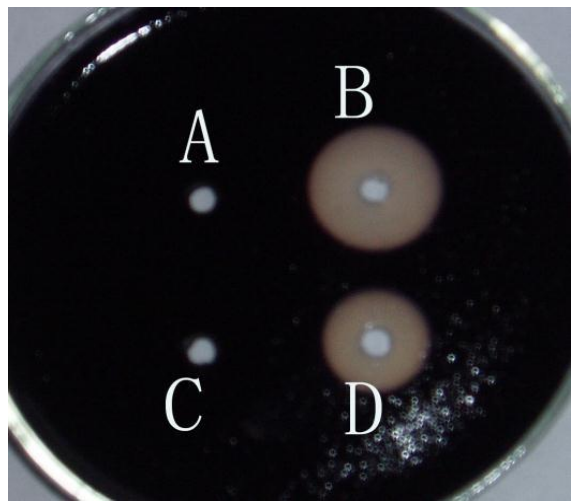

Figure 2. Starch-iodine agar plate for screening of $\beta$-lactamase inhibitor. Well A contained penicillin solution (negative control). However, well $B$ contained a mixture of $\beta$-lactamase and penicillin solutions. On the other hand, Well $C$ contained $\beta$-lactamase, $\mathbf{H g C l}_{2}$, and penicillin solutions (positive control). Well D contained plant extract, penicillin and $\beta$-lactamase solutions (14).

\section{Results:}

The results presented in Table 1 and Fig. 3 as well as Table 2 and Fig. 4 proved that the starchiodine method could be applied for detection of beta-lactamase inhibition from the various plant extracts. Since only penicillin $\mathrm{G}$ cannot react with iodine, there was no transparent zone around well A.

Penicillin $\mathrm{G}$ is broken by $\beta$-lactamase to penicillinoic acid which in turn reacts with iodine forming a colorless complex, which appeared as clear transparent zone surrounding well B. Since $\mathrm{HgCl}_{2}$ is an inhibitor of beta-lactamase activity, no transparent zone was observed surrounding well $\mathrm{C}$ 
similar to that of negative control of well A. Since transparent zones were formed around the 10 wells which were filled with plant extracts; this revealed the activity of beta-lactamase by the plant extracts.

The results showed that extracts from three plants $(C$. roseus, $E$. camaldulensis and $S$. terebinthifolius) expressed an inhibitory effect on $\beta$ lactamase originated from $S$. sciuri. The inhibition rate of the acetone extract of $C$. roseus attained $80 \%$, followed by its ethanol extracts $(65 \%)$ then its aqueous extract (25\%). In case of E. camaldulensis, the inhibition rate of its acetone extract was $70 \%$, then the inhibition rate of its ethanol and aqueous extracts reaching $55 \%$ and $10 \%$, respectively. Extract of $S$. terebinthifolius expressed similar inhibition rate on $\beta$-lactamase as those of $E$. camaldulensis, acetone extract (70\%) aqueous
$(15 \%)$ and ethanol extracts $(55 \%)$.

On the other hand, extracts from $E$. camaldulensis and $S$. terebinthifolius showed an inhibitory effect on $\beta$-lactamases derived from $K$. pneumoniae. The inhibition rate of acetone extract from E. camaldulensis reached $75 \%$, while its aqueous and ethanol extracts inhibited $15 \%$ and $55 \%$ of the enzyme activity, respectively.

The inhibition of $\beta$-lactamase by acetone extract of S. terebinthifolius reached $80 \%$, but its aqueous and ethanol extracts inhibited $25 \%$ and $65 \%$, respectively. Thus, the results of the current study indicated that acetone extracts expressed the strongest inhibition (ranging $70-80 \%$ ) on $\beta$ lactamase activity of both origins compared to their aqueous and ethanolic extracts.

Table 1. Inhibition rate of ten medicinal plant extracts on $\beta$-lactamase originated from Staphylococcus sciuri.

\begin{tabular}{|c|c|c|c|c|c|c|c|}
\hline \multirow[t]{2}{*}{ NO. } & \multirow[t]{2}{*}{ Plants } & \multicolumn{3}{|c|}{$\begin{array}{l}\text { The diameter of the transparent } \\
\text { zones }(\mathrm{mm})\end{array}$} & \multicolumn{3}{|c|}{ Inhibition rate $(\%)$} \\
\hline & & $\begin{array}{l}\text { Acetone } \\
\text { extract }\end{array}$ & $\begin{array}{c}\text { Aqueous } \\
\text { extract }\end{array}$ & $\begin{array}{l}\text { Ethanol } \\
\text { extract }\end{array}$ & $\begin{array}{c}\text { Acetone } \\
\text { extract }\end{array}$ & $\begin{array}{c}\text { Aqueous } \\
\text { extract }\end{array}$ & $\begin{array}{r}\text { Ethanol } \\
\text { extract }\end{array}$ \\
\hline & Control wells & & & & & & \\
\hline A & Penicillin G & 0 & 0 & 0 & & & \\
\hline B & Enzyme + penicillin G & $25 \pm 0.6$ & $25 \pm 0.4$ & $25 \pm 0.5$ & & & \\
\hline $\mathrm{C}$ & $\mathrm{HgCl}_{2}+$ Enzyme + penicillin $\mathrm{G}$ & 0 & 0 & 0 & & & \\
\hline 1 & A. indica & $25 \pm 0.6$ & $25 \pm 0.6$ & $25 \pm 0.7$ & 0 & 0 & 0 \\
\hline 2 & C. papaya & $25 \pm 0.5$ & $25 \pm 0.6$ & $25 \pm 0.5$ & 0 & 0 & 0 \\
\hline 3 & C. roseus & $9 \pm 0.4$ & $20 \pm 0.6$ & $12 \pm 0.4$ & 80 & 25 & 65 \\
\hline 4 & C. silique & $25 \pm 0.6$ & $25 \pm 0.7$ & $25 \pm 0.6$ & 0 & 0 & 0 \\
\hline 5 & E. camaldulensis & $11 \pm 0.4$ & $23 \pm 0.5$ & $14 \pm 0.3$ & 70 & 10 & 55 \\
\hline 6 & F. sycomorus & $25 \pm 0.3$ & $25 \pm 0.7$ & $25 \pm 0.6$ & 0 & 0 & 0 \\
\hline 7 & M. oleifera & $25 \pm 0.6$ & $25 \pm 0.8$ & $25 \pm 0.4$ & 0 & 0 & 0 \\
\hline 8 & O. basilicum & $25 \pm 0.5$ & $25 \pm 0.4$ & $25 \pm 0.7$ & 0 & 0 & 0 \\
\hline 9 & S. terebinthifolius & $11 \pm 0.2$ & $22 \pm 0.6$ & $14 \pm 0.3$ & 70 & 15 & 55 \\
\hline 10 & W. somnifera & $25 \pm 0.6$ & $25 \pm 0.8$ & $25 \pm 0.4$ & 0 & 0 & 0 \\
\hline
\end{tabular}

Each value represents the means of triplicates $\pm \mathrm{SD}, \mathrm{A}=$ penicillin $\mathrm{G}$ solution (negative control), $\mathrm{B}=\beta$-lactamase solution + penicillin $\mathrm{G}$ solution, $\mathrm{C}=\mathrm{HgCl}_{2}$ solution $+\beta$-lactamase solution + penicillin $\mathrm{G}$ solution (positive control), Blank = Not calculated.
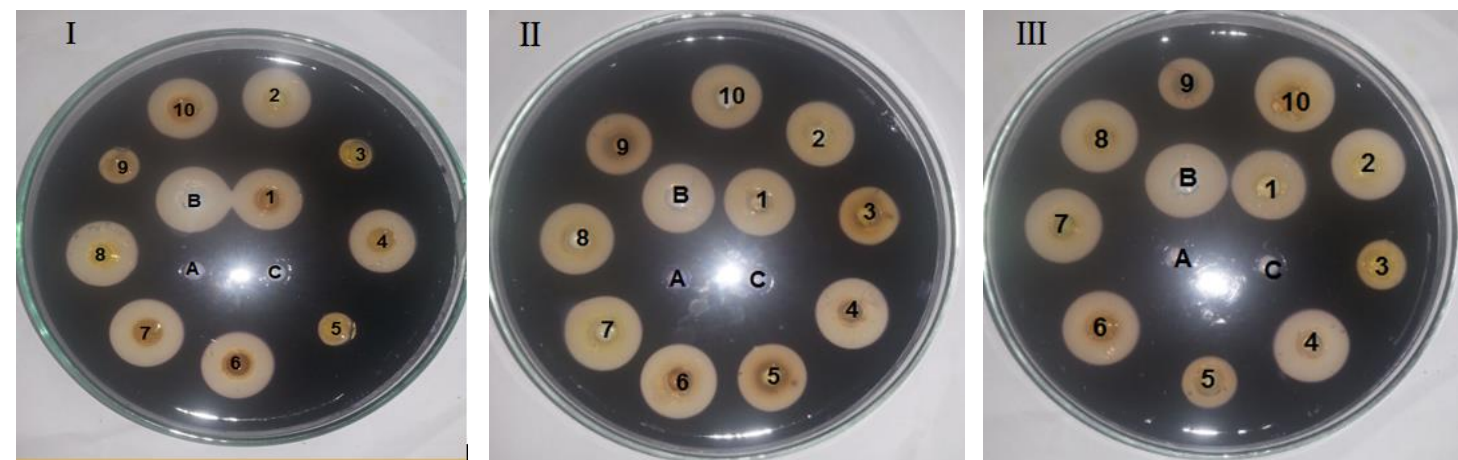

Figure 3. (I, II, III): Screening of $\beta$-lactamase activity derived from Staphylococcus sciuri by ten plant extracts. (I) Inhibitory effect of plant acetone extracts on $\beta$-lactamase from $S$. sciuri. (II) Inhibitory influence of plant aqueous extracts on $\beta$-lactamase from $S$. sciuri. (III) Inhibitors influence of plant ethanolic extracts on $\quad \beta$-lactamase from $S$. sciuri. 
$A=$ penicillin $G$ solution (negative control), $\mathrm{B}=\beta$-lactamase solution + penicillin $\mathrm{G}$ solution, $\mathrm{C}=$ $\mathrm{HgCl}_{2}$ solution $+\beta$-lactamase solution + penicillin $\mathrm{G}$ solution (positive control), $(1-10=$ plants extract $+\beta$-lactamase solution + penicillin solution $),\{1=$
A. indica, $2=C$. papaya, $3=C$. roseus, $4=C$. silique, $5=$ E. camaldulensis, $6=F$. sycomorus, $7=M$. oleifera, $8=O$. basilicum, $9=S$. terebinthifolius, 10 $=W$. somnifera $\}$.

Table 2. Inhibition rate of ten medicinal plant extracts on $\beta$-lactamase derived from Klebsiella pneumonia.

\begin{tabular}{|c|c|c|c|c|c|c|c|}
\hline \multirow{2}{*}{ NO. } & \multirow{2}{*}{ Plants } & \multicolumn{3}{|c|}{$\begin{array}{l}\text { The diameter of the transparent zones } \\
\qquad(\mathrm{mm})\end{array}$} & \multicolumn{3}{|c|}{ Inhibition rate $(\%)$} \\
\hline & & $\begin{array}{l}\text { Acetone } \\
\text { extract }\end{array}$ & $\begin{array}{l}\text { Aqueous } \\
\text { extract }\end{array}$ & $\begin{array}{l}\text { Ethanol } \\
\text { extract }\end{array}$ & $\begin{array}{l}\text { Acetone } \\
\text { extract }\end{array}$ & $\begin{array}{l}\text { Aqueous } \\
\text { extract }\end{array}$ & $\begin{array}{l}\text { Ethanol } \\
\text { extract }\end{array}$ \\
\hline A & $\begin{array}{l}\text { Control wells } \\
\text { penicillin } \mathrm{G}\end{array}$ & 0 & 0 & 0 & & & \\
\hline $\mathrm{B}$ & Enzyme+ Penicillin G & $25 \pm 0.6$ & $25 \pm 0.4$ & $25 \pm 0.5$ & & & \\
\hline $\mathrm{C}$ & $\underset{G}{\mathrm{HgCl}_{2}}+\underset{\text { Enzyme }}{\text { En penicillin }}$ & 0 & 0 & 0 & & & \\
\hline 1 & A. indica & $25 \pm 0.7$ & $25 \pm 0.6$ & $25 \pm 0.7$ & 0 & 0 & 0 \\
\hline 2 & C. papaya & $25 \pm 0.8$ & $25 \pm 0.7$ & $25 \pm 0.6$ & 0 & 0 & 0 \\
\hline 3 & C. roseus & $25 \pm 0.6$ & $25 \pm 0.8$ & $25 \pm 0.8$ & 0 & 0 & 0 \\
\hline 4 & C. silique & $25 \pm 0.5$ & $25 \pm 0.6$ & $25 \pm 0.7$ & 0 & 0 & 0 \\
\hline 5 & E. camaldulensis & $10 \pm 0.3$ & $22 \pm 0.7$ & $14 \pm 0.4$ & 75 & 15 & 55 \\
\hline 6 & F. sycomorus & $25 \pm 0.6$ & $25 \pm 0.6$ & $25 \pm 0.8$ & 0 & 0 & 0 \\
\hline 7 & M. oleifera & $25 \pm 0.4$ & $25 \pm 0.8$ & $25 \pm 0.6$ & 0 & 0 & 0 \\
\hline 8 & O. basilicum & $25 \pm 0.8$ & $25 \pm 06$ & $25 \pm 0.7$ & 0 & 0 & 0 \\
\hline 9 & S. terebinthifolius & $9 \pm 0.3$ & $20 \pm 0.7$ & $12 \pm 0.4$ & 80 & 25 & 65 \\
\hline 10 & W. somnifera & $25 \pm 0.4$ & $25 \pm 0.7$ & $25 \pm 0.6$ & 0 & 0 & 0 \\
\hline
\end{tabular}

Each value represents the means of triplicates $\pm \mathrm{SD}, \mathrm{A}=$ penicillin $\mathrm{G}$ solution (negative control), $\mathrm{B}=\beta$-lactamase solution + penicillin $\mathrm{G}$ solution, $\mathrm{C}=\mathrm{HgCl}_{2}$ solution $+\beta$-lactamase solution + penicillin $\mathrm{G}$ solution (positive control), Blank = Not calculated.
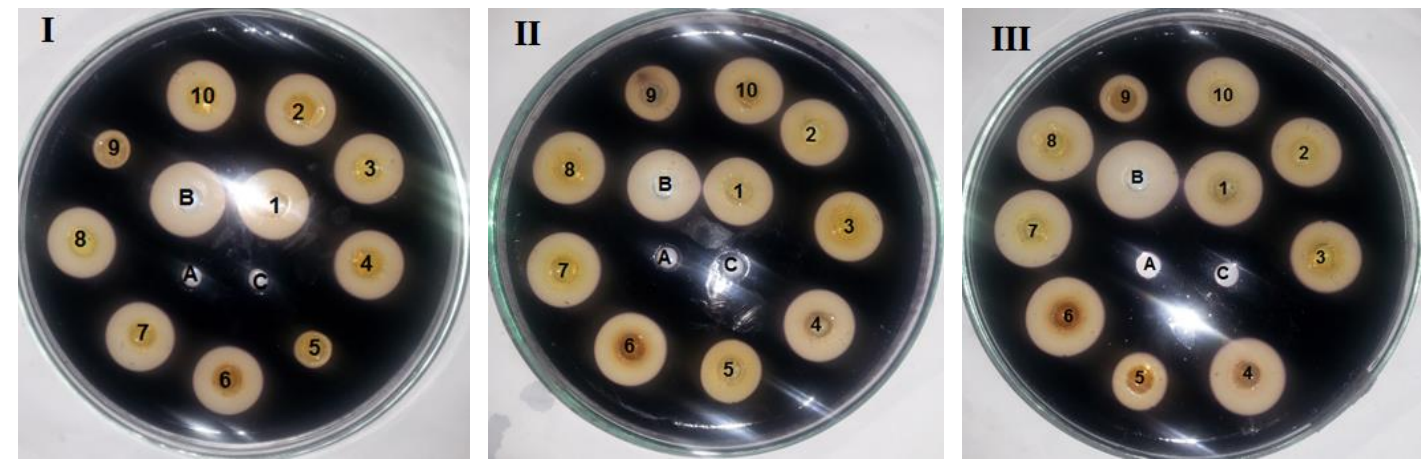

Figure 4. (I, II, III): Screening the inhibition of $\beta$-lactamase derived from Klebsiella pneumoniae by ten plant extracts. (I) Inhibitory influence of plant acetone extracts on $\beta$-lactamase from $K$. pneumonia. (II) Inhibitory influence of plant aqueous extracts on $\beta$-lactamase from $K$. pneumoniae. (III) Inhibitory influence of plant ethanol extracts on $\beta$-lactamase $K$. pneumonia.

$\mathrm{A}=$ penicillin $\mathrm{G}$ solution (negative control), $\mathrm{B}=\beta$-lactamase solution + penicillin $\mathrm{G}$ solution, $\mathrm{C}$ $=\mathrm{HgCl}_{2}$ solution $+\beta$-lactamase solution + penicillin $\mathrm{G}$ solution (positive control), $(1-10=$ plants extracts $+\beta$-lactamase solution + penicillin solution $),\{1=$
A. indica, $2=C$. papaya, $3=C$. roseus, $4=C$. silique, $5=$ E. camaldulensis, $6=F$. sycomorus, $7=M$. oleifera, $8=$ O. basilicum, $9=S$. terebinthifolius, 10 $=$ W. somnifera $\}$. 


\section{Discussion:}

In the present investigation, starch-iodine agar plate was a screening method adopted for the detection of $\beta$-lactamase inhibitors. This method is simple, inexpensive and gives clear visible results (15). It is also acceptable for the detection of plant extracts which cause inhibition of $\beta$-lactamase (16).

The results in the present investigation showed an inhibitory effect of leaf extracts from $C$. roseus, E. camaldulensis and S. terebinthifolius on $\beta$-lactamase from $S$. sciuri. However, the extracts from A. indica, $C$. papaya, $C$. silique, $F$. sycomorus, $M$. oleifera, $O$. basilicum and $W$. somnifera did not show inhibition of $\beta$-lactamase.

The results also indicated that leaf extracts

of E. camaldulensis and $S$. terebinthifolius exhibited an inhibitory effect against the enzyme originated from $K$. pneumoniae. However, extracts from A. indica, C.papaya, C. roseus, C. silique, $F$. sycomorus, $M$. oleifera, $O$. basilicum and $W$. somnifera did not show any inhibitory effect on the enzyme from $K$. pneumoniae.

In support, other plant extracts from Terminalia chebula, Terminalia bellirica, and Ocimum tenuiflorum inhibited bacterial $\beta$-lactamase enzyme in vitro (17). Also, Abdallah et al. (7) reported the inhibition of $\beta$-lactamase by nineteen crude extracts from Saudi plants belonging to eight families.

Solanki and Selvanayagam investigated the effect of fifteen plants on $\beta$ lactamase activity and they have reported that the extracts of these plants showed an inhibitory effect on $\beta$-lactamase activity. Shaikh et al. (5) reported that extracts from seeds and peels of various plants including brahmi (Bacopa monnieri), gurmar (Gymnema sylvestre), satavar (Asparagus racemosus), garlic (Allium sativum), baheda (Terminalia bellerica), pomegranate (Punica granatum) and ginger (Zingiber officinale) inhibited $\beta$-lactamase activity. Moreover, Akkiraju et al. (3) described an inhibitory effect on $\beta$-lactamase activity by extracts of, Allium sativum, Calotropis procera, Lawsonia inermis, Ocimum sanctum and Zingiber officinale.

Generally, medicinal plants are known by their bioactive metabolites such as alkaloids, tannins, flavonoids, terpenpoids, phenolics and saponins which are inhibitors of $\beta$-lactamase (19). Boussoualim et al. (20) recorded an inhibitory effect of several extracts of Globularia alypum and Anchusa azurea on a $\beta$-lactamase from Bacillus cereus and the inhibition was dose-dependent manner. Al Sahli and Abdulkhair (21) reported that extracts from Rumex vesicarius $\mathrm{L}$. expressed an inhibitory effect on $\beta$-lactamase enzyme and clavulanic acid was described as the inhibitory factor of $\beta$-lactamase activity.

Yang et al. (14) reported that the methanol extract of Fissistigma cavaleriei roots showed an inhibition of $\beta$-lactamase activity and salicylsalicylic has been described as the inhibitory agent of $\beta$-lactamase. Mandal et al (22) found that tannic acid, epicatechin, epigallocatechin gallate and quercetin as plant constituents inhibited $\beta$ lactamase activity. These authors suggested that the highest inhibition rate of $\beta$-lactamase was observed by epigallocatechin gallatea and tannic acid.

The results in the present work revealed the existence of promising crude plant extracts of some examined medicinal plants as inhibitors of $\beta$ lactamase activity from Staphylococcus sciuri and Klebsiella pneumonia. These plants were C. roseus, E. camaldulensis, and S. terebinthifolius. However, further studies are crucial for the analysis of these extracts for the identification of the active compounds. In addition, other studies are needed to assess the absence of toxicity of the most prominent tested plant extracts to recommend them as alternative approaches for bacterial resistance management.

\section{Authors' declaration:}

- Conflicts of Interest: None.

- We hereby confirm that all the Figures and Tables in the manuscript are mine ours. Besides, the Figures and images, which are not mine ours, have been given the permission for republication attached with the manuscript.

- Ethical Clearance: The project was approved by the local ethical committee in Mansoura University in Egypt.

\section{References:}

1. Horie H, Chiba A, Wada S. Inhibitory effect of soy saponins on the activity of $\beta$-lactamases, including New Delhi metallo- $\beta$-lactamase, J Food Sci Technol. 2018; 55(5): 1948-1952.

2. Askarinia M, Ganji A, Jadidi-Niaragh F, Hasanzadeh S, Mohammadi B, Ghalamfarsa F, et al. Review on medicinal plant extracts and their active ingredients against methicillin-resistant and methicillin-sensitive Staphylococcus aureus. J. Herbmed Pharmacol. 2019; 8(3): 315-320.

3. Akkiraju L J, Sowmya M, Deepthi C, Lakshmi V V. Herbal extracts as beta- lactamase inhibitors. Int. J. Sci. Eng. Res. 2015; 6 (2): 68-70.

4. Nader MI, Ghanima KK, Ali SA, Azhar DA. Antibacterial activity of ginger extracts and its essential oil on some of pathogenic bacteria. Baghdad Sci. J. 2010; 7(3):1159-1165.

5. Shaikh S, Lochan R, Kaul P, Tandon GD. Beta lactamase inhibitors from indigenous herbs and spices. Res. J. Pharm., Biol. Chem. Sci. 2014; 5 (2): 
275-385.

6. Al-Mossawei MT., Ali AH, Abid HS, Murad R H .Antimicrobial activity of ethanolic extracts of Raphanus sativus and Cyperus rotundus against some pathogenic bacteria and Candida albicans. Baghdad Sci. J. 2014; 11(2): 748-756.

7. Abdallah HM, Asfour HZ, El-Halawany AM, Elfaky MA. Saudi plants as a source of potential $\beta$-lactamase inhibitors. Pakistan J. Pharma. Sci. 2018; 31(1): 325332.

8. Abdou, R H, Saleh SY, Khalil WF. Toxicological and biochemical studies on Schinus terebinthifolius concerning its curative and hepatoprotective effects against carbon tetrachloride-induced liver injury. Pharmacogn. Mag. 2015; 11 (1): 93-101.

9. Gangoué-Piéboji J, Baurin S, Frère JM, Ngassam P, Ngameni B, Azebaze A, et al. Schinus terebinthifolius Raddi (Anacardiaceae) leaf extracts: Antibacterial activity against two Agrobacterium tumefaciens strains. J. Crop Prot. 2015; 4 (1): 85-96.

10. Al-Hayanni HSA, El-Shora HM .Beta-lactamase inhibitory effect of some medicinal plants. Res. j. pharm. biol. chem. sci. 2018; 9 (5): 263-274.

11. Ranade Y A, Dharmadhikari, S M, Wadegaonkar P A. Screening, production, purification and characterization of beta-lactamase from uropathogenic E. coli. Eur. J. Exp. Biol. 2013; 3 (1): 434-442.

12. Ghanney, N, Rhouma, A. Schinus terebinthifolius Raddi (Anacardiaceae) leaf extracts: Antibacterial activity against two Agrobacterium tumefaciens strains. J. Crop Prot. 2015;4 (1): 85-96.

13. Djeussi D E, Noumedem JA K, Seukep J A, Fankam A G, Voukeng I K, Tankeo S B, et al. Antibacterial activities of selected edible plants extracts against multidrug-resistant Gram-negative bacteria. BMC Complement. Altern. Med. 2013; 13: 164-171.

14. Yang Z, Niu Y, Le Y, Ma X, Qiao C. Beta-lactamase inhibitory component from the roots of Fissistigma cavaleriei. Phytomed. 2010; 17 (2): 139-141.

15. Das S, Kumar N, Vishweswaraiah R H, Haldar L, Gaare, M, Singh V K, et al. Microbial based assay for specific detection of $\beta$-lactam group of antibiotics in milk. J. Food Sci. Technol. 2014; 51(6): 1161-1166.

16. Kesharwani AK, Mishra J. Detection of $\beta$-lactamase and antibiotic susceptibility of clinical isolates of Staphylococcus aureus. Biocat. Agricul. Biotechnol. 2019; 17: 720-725.

17. Arora S, Nandi S. Reversion of antibiotic resistance with beta-lactamase inhibitor from medicinal plants. Asian J. Pharmac. Clin. Res. 2017; 10: 204-208.

18. Solanki SS, Selvanayagam M. Beta-lactamase inhibitory potential and antibacterial potentiation of certain medicinal plants and extracts against extended spectrum beta-lactamase producers. Adv. Bio. Tech. 2013; 12(7): 6-10.

19. Shakya AK. Medicinal plants: Future source of new drugs. Int. J. Herb. Med. 2016; 4(4): 59-64.

20. Boussoualim N, Trabsa H, Krache I, Arrar L, Baghiani, A. Anti-bacterial and $\beta$-Lactamase inhibitory effects of Anchusa azurea and Globularia alypum extracts. Res. J. Pharmac. Biolo. Chem. Sci. 2014; 5(1): 742-749.

21. Al Sahli AA, Abdulkhair WM .Inhibition of betalactamase enzyme of Pseudomonas aeruginosa by clavulanic acid of Rumex vesicarius L. Afr. J. Agric. Res.2011; 6 (12): 2908-2915.

22. Mandal S, Dias R, Franco O. Phenolic compounds in antimicrobial. J. Med. Food. 2017; 20(10): 10311038 .

\section{مستخلصات مختلفة لبعض التباتات الطبية كمثبطات لنشاط بيتا لاكتاماز}

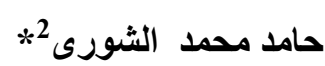

\section{* مدى سهيل عبد الحياني}

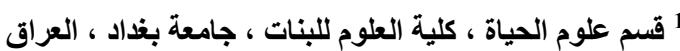

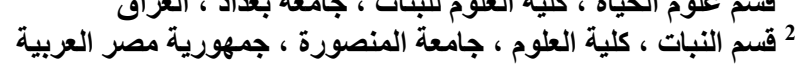

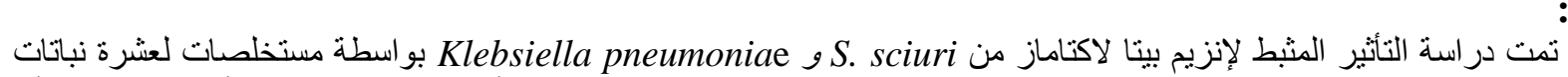

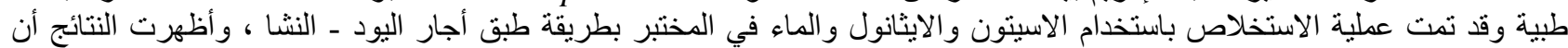

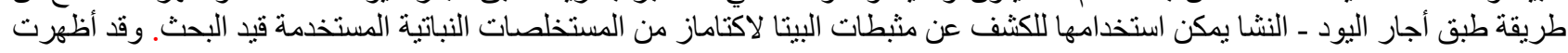

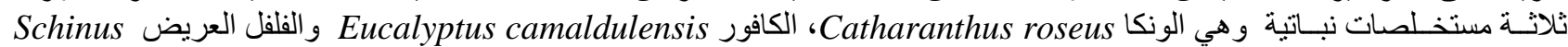
فعالية و اضحة لتثبيط بيتا لاكتاماز من Staphylococcus sciuri و وعلي الجانب الآخر أظهرت مستخلصات نباتات Eucalyptus camaldulensis الكافور والفلفل العريض Schinus terebinthifolius نشاط مثبطا لبيتا لاكتاماز المعزول من .Klebsiella pneumoniae

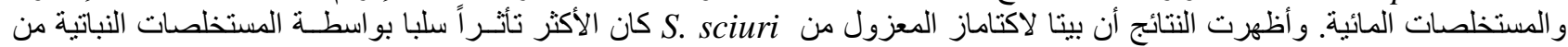

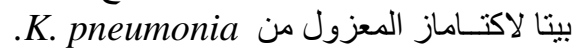

الكلمات المفتاحية: نشاط مضاد للجر اثيم ، نباتات طبية , الع 